\title{
Thermal Design Conception of China Brazil Earth Resources Satellite
}

Issamu Muraoka and Rosângela M.G. Leite

INPE

Brazil

José Luis F. Bastos

Copesp

Brazil 
The appearance of the ISSN code at the bottom of this page indicates SAE's consent that copies of the paper may be made for personal or internal use of specific clients. This consent is given on the condition, however, that the copier pay a $\$ 5.00$ per article copy fee through the Copyright Clearance Center, Inc. Operations Center, 27 Congress St., Salem, MA 01970 for copying beyond that permitted by Sections 107 or 108 of the U.S. Copyright Law. This consent does not extend to other kinds of copying such as copying for general distribution, for advertising or promotional purposes, for creating new collective works, or for resale.

SAE routinely stocks printed papers for a period of three years following date of publication. Direct your orders to SAE Customer Service Department.

To obtain quantity reprint rates, permission to reprint a technical paper or permission to use copyrighted SAE publications in other works, contact the SAE Publications Group.

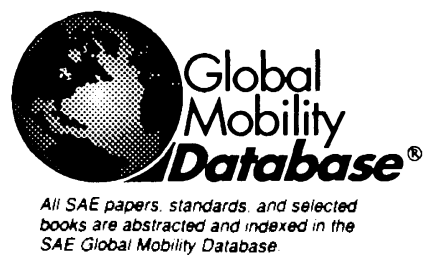

No part of this publication may by reproduced in any form, in an electronic retrieval system or otherwise, without the prior written permission of the publisher.

\section{ISSN 0148-7191}

Copyright 1991 Soclety of Automotive Engineers, Inc.

Positions and opinions advanced in this paper are those of the author(s) and not necessarily those of SAE. The author is solely responsible for the content of the paper. A process is available by which discussions will be printed with the paper if it is published in SAE transactions. For permission to publish this paper in full or in part, contact the SAE Publications Division.

Persons wishing to submit papers to be considered for presentation or publication through SAE should send the manuscript or a 300 word abstract of a proposed manuscript to: Secretary, Engineering Activity Board, SAE.

\section{Printed in USA}




\section{Thermal Design Conception of China Brazil Earth Resources Satellite}

Issamu Muraoka and Rosângela M.G. Leite

INPE

Brazil

José Luis F. Bastos

Copesp

Brazil

\section{Abstract}

This paper describes some general aspects of the thermal design of CBERS satellite and presents a detailed analysis of the battery and its compartment.

The battery compartment is analysed, using mathematical modelling, to calculate the radiator area and heater power consumption. The battery internal temperature gradients are estimated, also using mathematical modelling, to verify the cells package design.

The thermal package PCTER, developed in INPE, was used to create the thermal model where the temperature distributions are predicted by a thermal analyser based on finite differences.

\section{INTRODUCTION}

China Brazil Earth Resources Satellite (CBERS), jointly developed by the People's Republic of. China and Brazil, is a $1400 \mathrm{Kg}$ mass satellite with an EOL power of 1000 Watts (Figures 1 and 2). It is scheduled to be launched in 1994, by a Long March 4 vehicle, in a circular sun-synchronous orbit at an altitude of $778 \mathrm{Km}$.

The CBERS satellite will be used to remote sensing of natural resources and monitoring of the environment. Its payload consists of three imaging sensors: the wide-field imager (WFI), the high resolution CCD camera and the infrared multispectral scanner (IRMSS).

CAST (Chinese Academy of Space Technology) is responsable for the thermal control design of this satellite. However INPE (Brazilian Institute of Space Research) develops the same work to check the results obtained by the chinese group and propose, eventually, new solutions for the thermal control project. Also, INPE was subcontracted to execute the thermal design of the battery compartment.

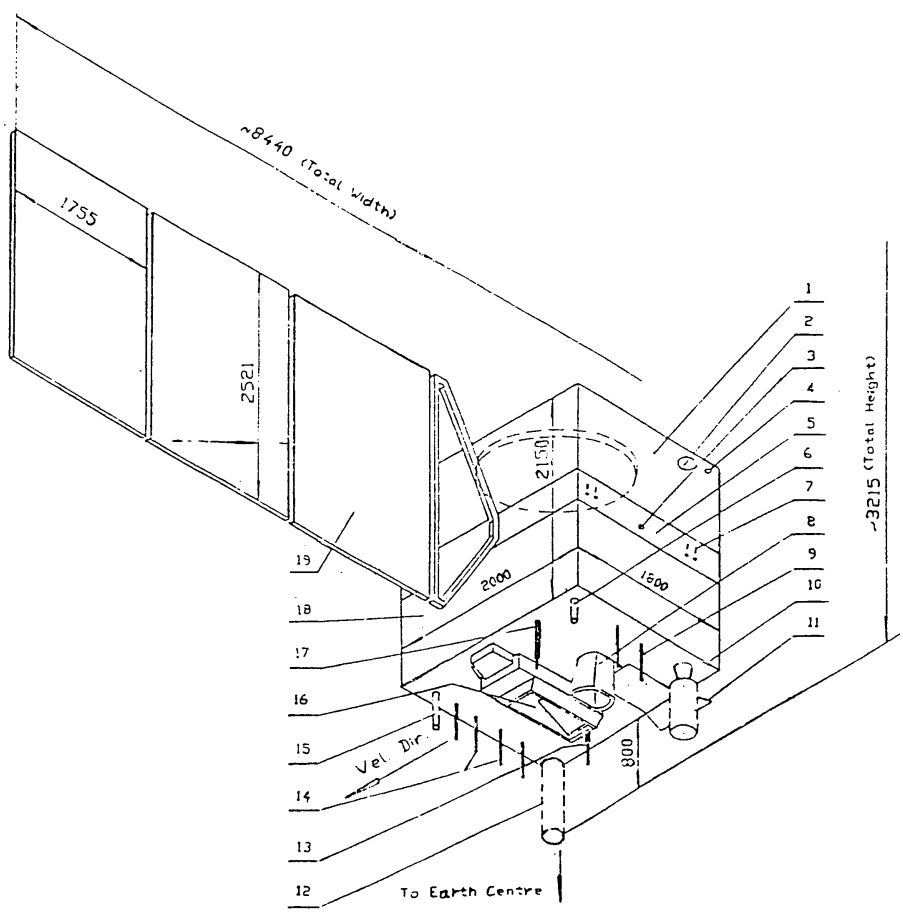

1 Service Module; 2 Infrared Earth Sensor; $320 \mathrm{~N}$ thruster Assembly; 4 Sun Sensor; 5 Middle Wall; 6 UHF Receive Antenna; 7 1N Thruster Assemb1y; 8 Infrared Scanner; 9 IR Transmit Antenna; 10 VHF Transmit Antenna; 11 Radiant Cooler; 12 UHF RX/TX Antenna; 13 S-band Antenna; 14 CCD transmit Antenna; 15 UHF Transmit Antenna; 16 Optical Mechanism; 17 S-band Antenna; 18 Payload Module; 19 Solar Array.

Fig. 1 CBERS configuration 

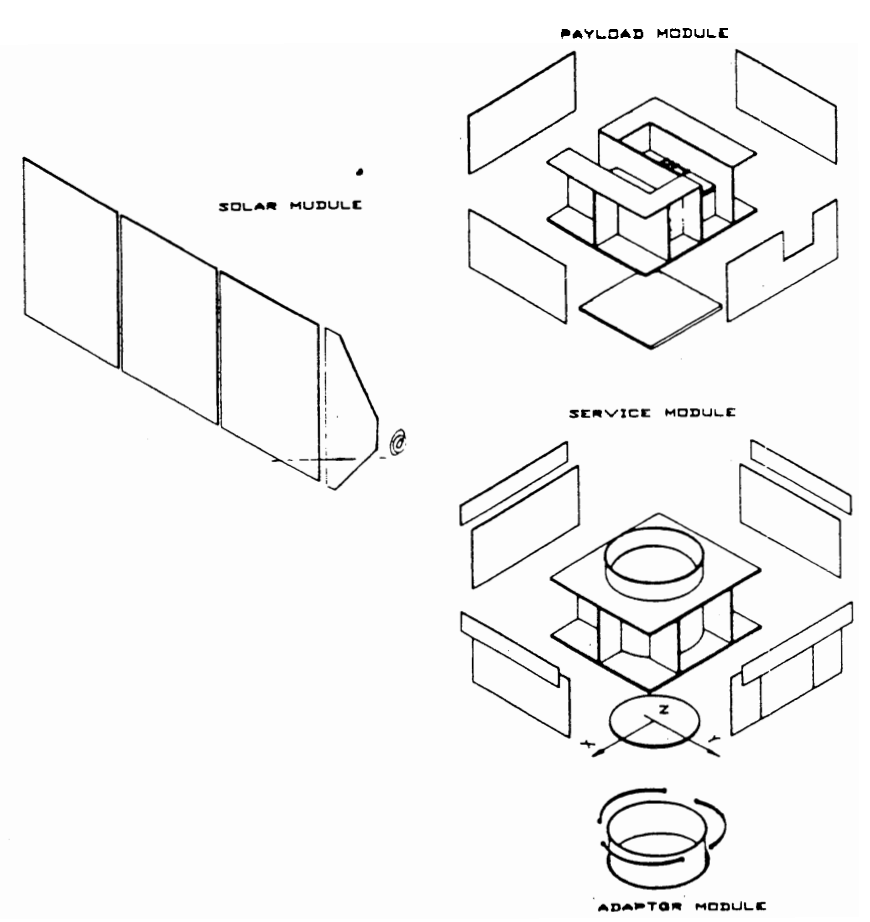

Fig. 2 CBERS Structure

The satellite global thermal design uses primarily a passive control to maintain all the spacecraft subsystems within the design temperature ranges during the expected mission phases. The thermal control subsystem meets the requirements applying flight proven design methods such as multilayer insulation blankets (MLI), paints, tapes, thermal interface materials, insulating washers and constant conductance heat pipes (CCHP).

Active thermal control, employing electrical heaters, is used for the propulsion subsystem for preventing the hydrazine freezing, batteries, and some payload equipments.

The thermal design of the batteries is based on two different levels of analysis. In the first, the global behaviour of the whole battery compartment is analysed, and the battery is dealt as isothermal body. With this analysis, the radiator area and heating power are determined to maintain the battery at its temperature specification limits.

In the second analysis, the battery is studied in its components level to verify the cells package design. This analysis uses the results of the battery compartment model as boundary conditions to calculate the temperature gradients inside the battery.

\section{SATELLITE GLOBAL IHERMAL DESIGN}

THERMAL DESIGN CONCEPTION The CBERS satellite uses a very common and simple technique for the global thermal design. Externally, the surfaces are insulated from the space environment using MLI and heat rejecting areas are created using optical solar reflector (OSR) and S-853 paint.

Internally, high emissivity coating are employed in order to have a good homogeneity of temperature. Exception is done for tanks, lines and valves of propulsion subsystem, battery, CCD camera, electro-optical module and IRMS scanner. These components, that have distinct temperatures specifications, are insulated conductively and radiatively from the satellite and they have a particular thermal control by heaters and radiator.

Constant conductance heat pipes of two flow channels and extruded axial grooves, having ammonia as working fluid, are installed inside the honeycomb panels to decrease the temperature gradients along the high dissipation equipment panels, as TWT's and battery discharge regulator (BDR). See Figure 3 .
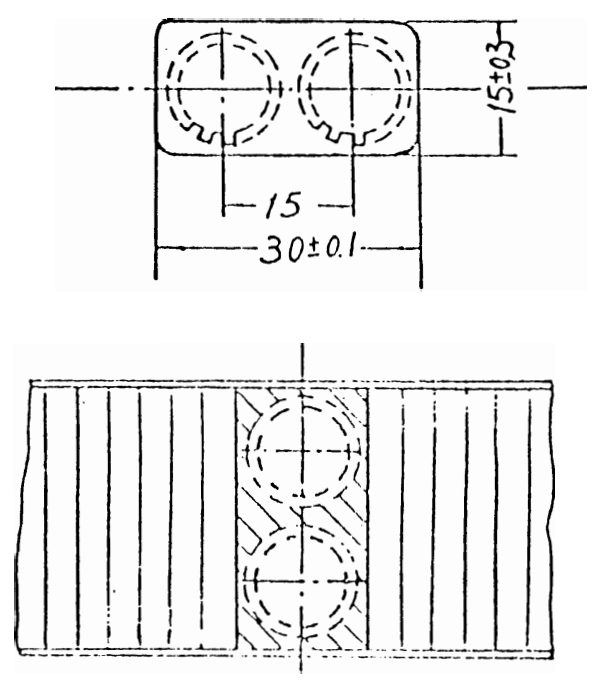

Fig. 3 Heat pipe configuration

The payload module is thermally insulated from the service module due to the multi-mission purpose, so that it is possible to have an independent thermal control for each module.

THERMAL MODELIZATION The thermal control solutions are met through the nodal method mathematical modelization. The temperature distribution of the satellite is predicted by two distinct thermal analysers, both based on finite differences. One analyser was developed by Chinese Academy of Space Technology and the other developed by Thermal Group from INPE. The results obtained for the analysis through the two analysers are very close.

In this phase of design conception only steady state analysis, with average thermal 
load, are done. The Equipment boxes are merged into the respective mounting panel. The payload and service module are divided in 169 and 138 isothermal nodes respectivelly.

The shape factors between surfaces are calculated by contour integration or double discretization method depending if there are or not blocking surfaces. The radiative couplings are calculated by Gebhart method.

The conductive couplings are calculated just between nodes on the same panel. Conductive couplings through the panel junctions are neglected.

The external loads from the Sun, albedo and the Earth are calculated numerically.

The critical cold and hot cases are simulated. The cold case occurs at the following conditions:

- minimum solar constant $1326 \mathrm{~W} / \mathrm{m} 2$;

- minimum solar incidence area (solar aspect angle $=73$ degrees);

- minimum internal dissipation;

- maximum eclipse time (34.9 minutes);

- BOL values of coating absortance.

For the hot case,the following conditions are simulated:

- maximum solar constant $1418 \mathrm{~W} / \mathrm{m} 2$;

- maximum solar incidence area (solar aspect angle $=66$ degrees);

- maximum internal dissipation;

- minimum eclipse time (33.5 minutes;)

- EOL values of coating absortance.

The Figures 4 and 5 show the diagram comparing the predicted and specified operating temperatures. The equipment qualification limits of temperatures is $10 \mathrm{C}$ colder and $10 \mathrm{C}$ hotter than the range presented in the diagram.

\section{BATTERY COMPARTMENT THERMAL DESIGN}

The operational parameters of a battery, such as voltage, capacity, efficiency and life time, are very dependent of the thermal environment and internal thermal gradients. A rigid thermal specification is imposed to the battery to attend its operational requirement.

In this analysis the thermal behavior of the battery compartment is studied, supposing that the battery is an isothermal body. The radiator area and heating power can be determinated, in function of the battery temperature limits specification.

The necessary radiative area for keeping the battery temperature below $15 \mathrm{C}$ is determined using the EOL heat dissipation. And the necessary heat consumption for keeping the battery temperature above $-5 \mathrm{C}$ during the $\mathrm{BOL}$ is also evaluated.

The average heat dissipations of each battery pack for the BOL and EOL are $9.9 \mathrm{~W}$ and $27.5 \mathrm{~W}$ respective11y.

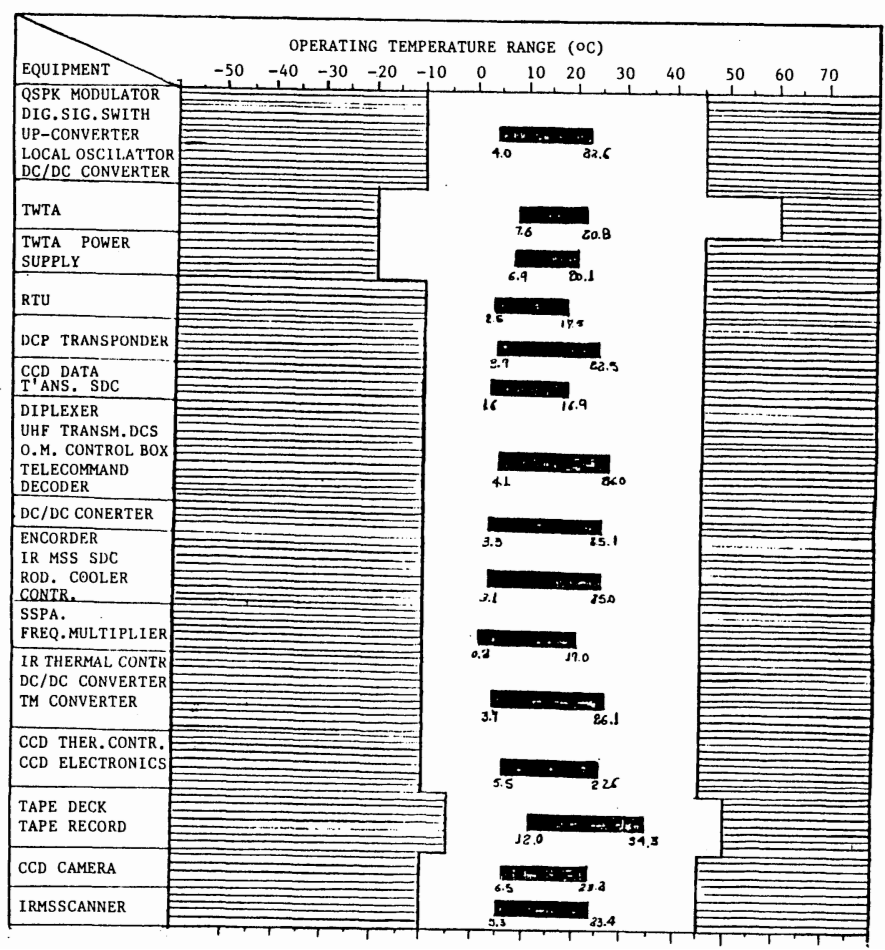

Fig. 4 Specified and predicted temperatures of payload module equipments

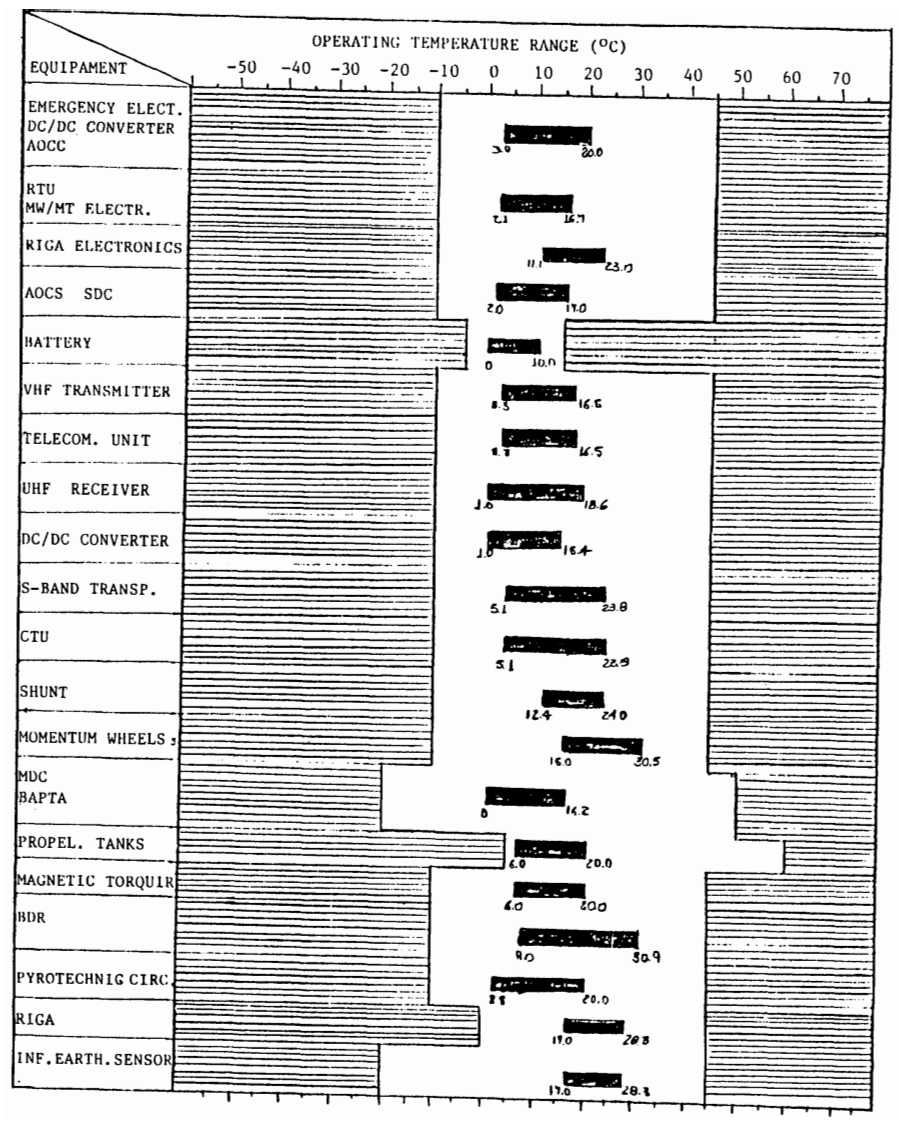

Fig. 5 Specified and predicted temperatures of service module equipments 
The specified temperature range of the panels which compose the battery compartment is from $0 \mathrm{C}$ to $35 \mathrm{C}$, respectively for cold and hot cases.

The thermal control design of the Battery Compartment is based on the following concepts: a) all internal surface of the compartment shall be covered with MLI in order to decouple them radiatively;

b) the battery mounting panel shall be insulated conductively from the others compartment panels so that the influence of the platform on the battery thermal behaviour is minimized;

c) a radiator for each battery pack must be sized and employ high emissivity coatings on the external surfaces of the panel regions where the batteries are fixed and the rest of panel external surfaces must be covered by MLI; d) each battery pack shall be conductively coupled to the mounting panel through an interfiller.

THERMAL MODELIZATION The Battery Compartment was divided in 369 isothermal nodes as shown in the Figures 6 and 7 .

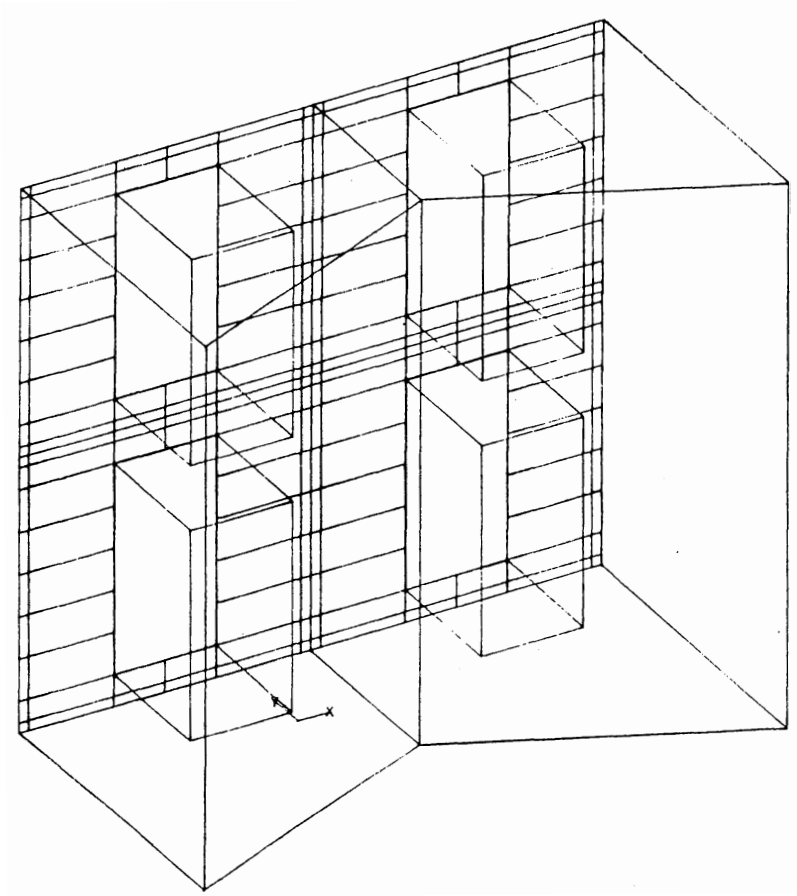

Fig. 6 View of the whole Battery Compartment

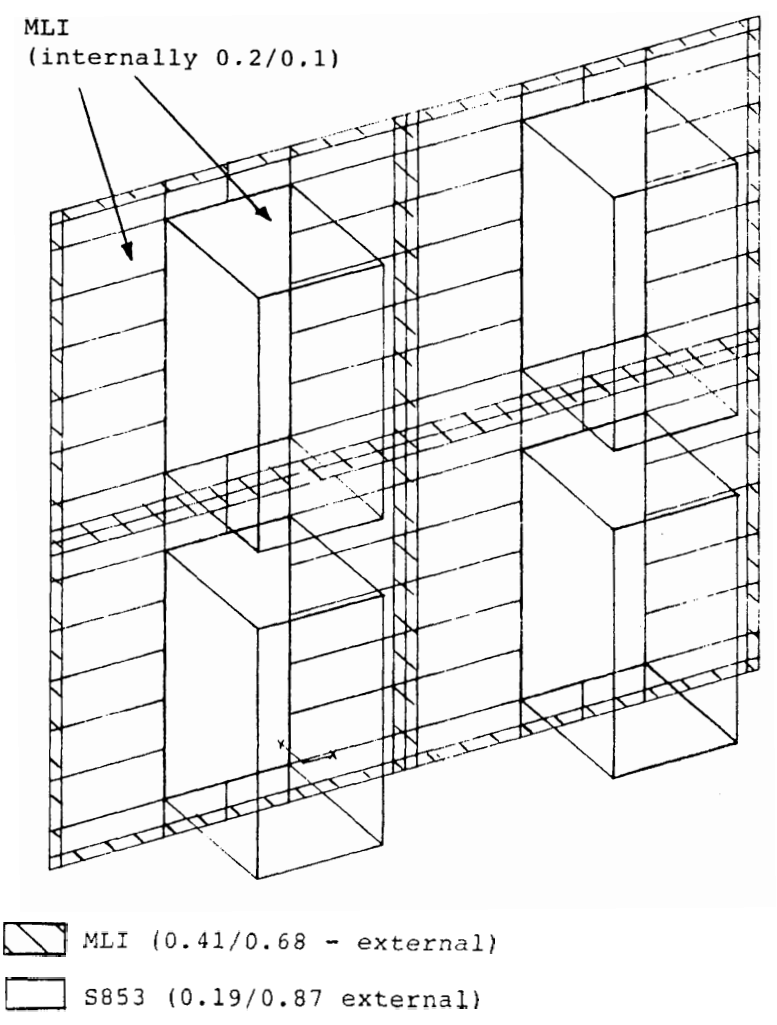

Fi.g. 7 View of the batteries on the mounting pane 1

The values of the thermal conductivities of the honeycomb and the thermal control elements were considered according to Table 1 :

Table 1: Thermal Conductivities

$\mid$\begin{tabular}{|l|l|} 
honeycomb & $\begin{array}{l}\text { tangencial to } \\
\text { the pane1 } \\
\text { pane1 }\end{array}\left|\begin{array}{l}\text { transversal } \\
\text { to the panel }\end{array}\right|$ \\
\hline RTV 566
\end{tabular}

For the junctions between the batteries mounting panel and the compartment panels, the estimated thermal resistance is $32 \mathrm{C} / \mathrm{W}$ for each bolt. 
The radiative couplings were obtained numerically from the geometry and thermo-optical properties of the battery compartment surfaces, such as defined in Table 2:

Table 2: Thermo-optical Properties

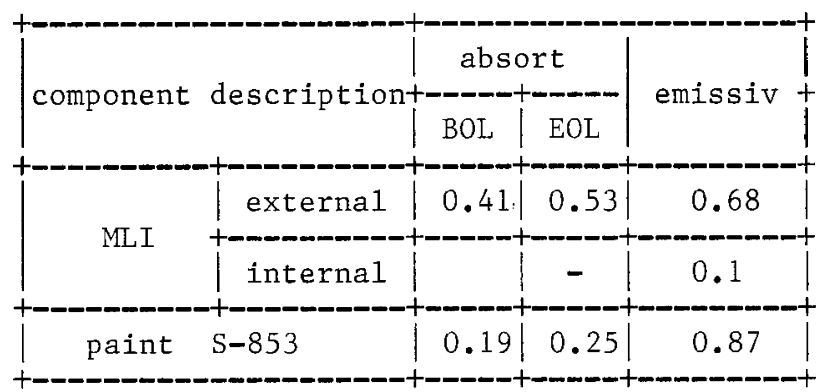

The albedo and Earth radiation incident on the battery mounting panel were calculated numerically for hot and cold cases.

The input data comprised:

a) orbit parameters:

inclination $=98.5$ degrees

altitude $=778000 \mathrm{~m}$

period $=6000$ seconds

b) solar constant

- hot case : $1418 \mathrm{~W} / \mathrm{m}^{2}$

- cold case: $1326 \mathrm{~W} / \mathrm{m}^{2}$

c) albedo: 0.34

d) Earth average temperature :250 K

RESULTS Initially the hot case is simulated to estimate the radiative area necessary to maintain the battery temperature below $15 \mathrm{C}$ in the EOL.

For hot case the following conditions are used:

Watts

- battery heat dissipation (EOL) $=27.54$

- compartment panels temperature $=35 \mathrm{C}$

With these conditions, a radiator of 0.163 $\mathrm{m} 2(0.420 \mathrm{~m} \times 0.388 \mathrm{~m})$ is necessary to maintain the battery at temperature of $11 \mathrm{C}$.

Taking the calculated radiator area, the cold case is simulated to determine the heat consumption necessary to keep the battery temperature above $-5 \mathrm{C}$ during the BOL. The cold case is characterized by:

- battery heat dissipation (BOL) $=9.90$ Watts:

- compartment panels temperature $=0 \mathrm{C}$. The simulation concluded that the additional power heating of $18 \mathrm{~W}$ for each battery pack is necessary to maintain the batteries at temperature of $0.6 \mathrm{C}$.

THERMAL ANALYSIS OF THE Ni-Cd BATTERY PACKAGE

Besides the temperature level, the battery
has tight specification of temperature gradients.
The objective of this study is verify the viability of a battery package design, related to thermal point of view, in function of temperature gradient specification.

Three factors are investigated.

a) battery temperature leve1;

b) temperature gradient between cells;

c) temperature gradient inside the cells.

Two mathematical models, based on nodal method, are developed. First, a complete mode1 is implemented. It comprises the whole body of a battery and part of mounting pane1 (area of radiator). The discretization is sufficient to identify one temperature for each cell. With this model, the temperature level and the gradient between cells can be verified.

The second model comprises just a quarter of the complete model, but it presents a finer discretization, that is sufficient to verify gradients inside the cells.

BATTERY CONFIGURATION The four battery packs of CBERS satellite are installed on the internal face of shadow panel of service module. The lay out is presented in Figure 7.

The external face of the panel is covered with high emissivity coating (area of $.388 \mathrm{~m} x$ $.420 \mathrm{~m}$ ) to reject the heat dissipated in the battery (emissivity $=0.87$ ).

The internal face of the panel and the surfaces of the battery are covered by MLI, to insulate the battery from other parts of the satelite.

Each battery is composed by $18 \mathrm{Ni}-\mathrm{Cd}$ cells. The cells are arranged in two lines of 9 cells and compressed by means of draw bars. The cells are covered with polymide pressuresensitive adhesive tapes for electrical insulation. Aluminium intercalary plates (thickness of $0.5 \mathrm{~mm}$ ) are placed between cells. The tickness of front and back plates is $2 \mathrm{~mm}$. The base plate is $4 \mathrm{~mm}$ tick with gap of $1 \mathrm{~mm}$ in the bottom side.This gap is filled with silicone rubber. See Figure 8 .

DESCRIPTION OF THE CELL The configuration of the cell is presented in Figure 9, and the Table 3 presents the data of each component of the cell.

The electrodes are placed in the case in alternated way (negative electrode alternated with positive electrode), and they are electrically insulated with $0.3 \mathrm{~mm}$ thick nylon separator.

The first and last electrode are in direct contact with the case. 
Table 3. Description of the cell

\begin{tabular}{|c|c|c|c|c|c|c|}
\hline component & qte & material & $\begin{array}{l}\text { d I me } \\
\text { l. }\end{array}$ & $\int_{t}^{e n s i o r}$ & $\frac{m \pi n}{h}$ & $\begin{array}{r}\text { mass } \\
(\mathrm{g})\end{array}$ \\
\hline case & 1 & stainless & 75 & 30 & 185 & 145 \\
\hline cover & 1 & stainless & 74 & 0.5 & 29 & 9.2 \\
\hline neg plate & 12 & cadmium & 70 & 0.9 & 144 & 34 \\
\hline pos plate & 11 & nfcke1 & 70 & 0.9 & 144 & 33 \\
\hline separator & 1 & nylon & 830 & 0.3 & 310 & 23 \\
\hline neg terminal & 1 & stainless & dian & m 8 & 15 & 7.3 \\
\hline pos terminal & 1 & stainless & dtan & in 8 & 15 & 7.3 \\
\hline $\begin{array}{l}\text { collector } \\
\text { insulating }\end{array}$ & 2 & $\begin{array}{l}\text { stainless } \\
\text { polychloro }\end{array}$ & 15 & 20 & 10 & 6.5 \\
\hline $\begin{array}{l}\text { spacer } \\
\text { plastic }\end{array}$ & 1 & $\begin{array}{l}\text { ethylene } \\
\text { polyacry }\end{array}$ & 74 & 28 & 175 & 6.9 \\
\hline $\begin{array}{l}\text { supportor } \\
\text { electrolyte }\end{array}$ & 1 & $\begin{array}{ll} & \text { lene } \\
30 \% & \mathrm{KOH}\end{array}$ & 65 & 27 & & $\begin{array}{c}7 \\
145\end{array}$ \\
\hline total & & & & & & 424.2 \\
\hline
\end{tabular}
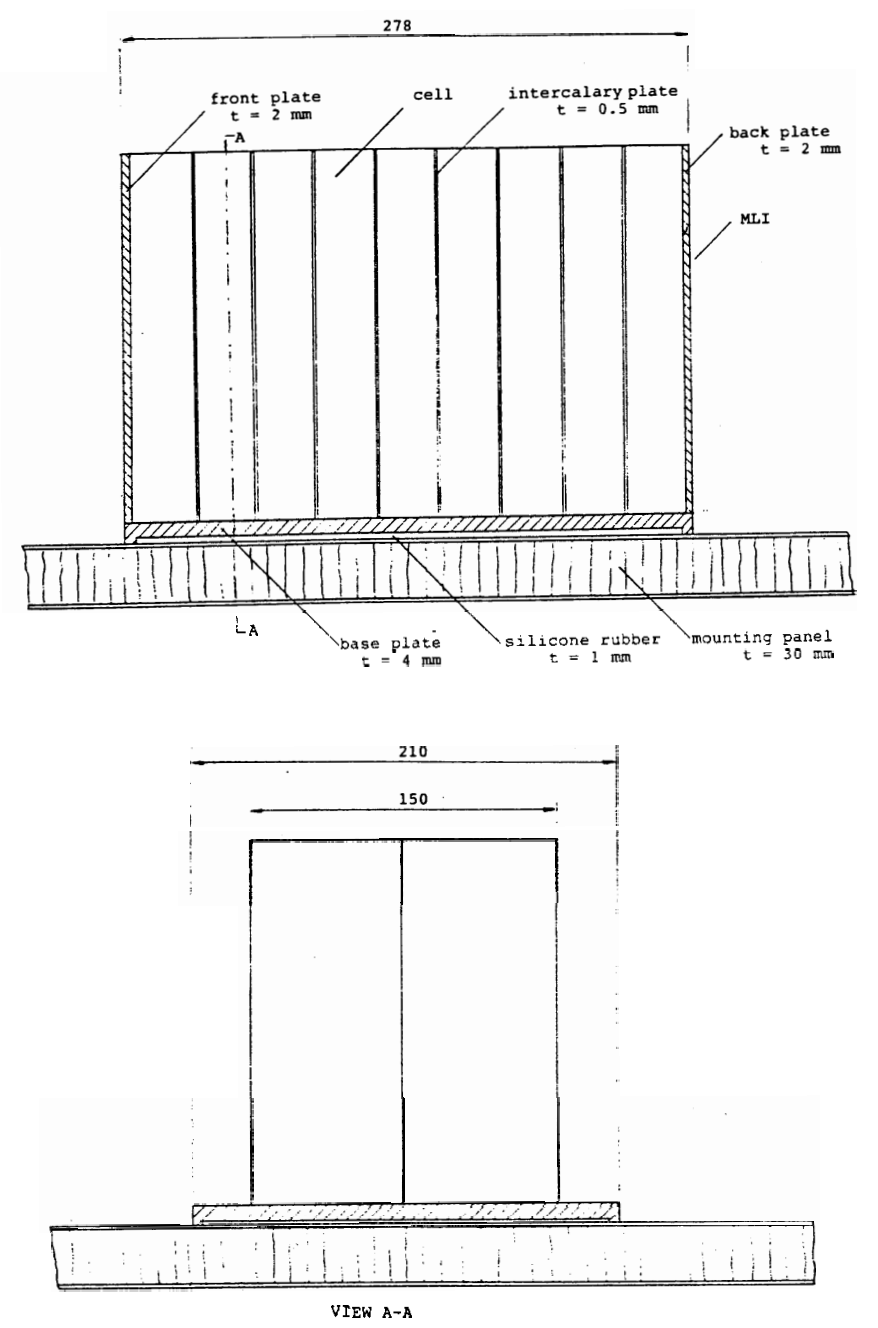

Fig. 8. Configuration of the battery package.

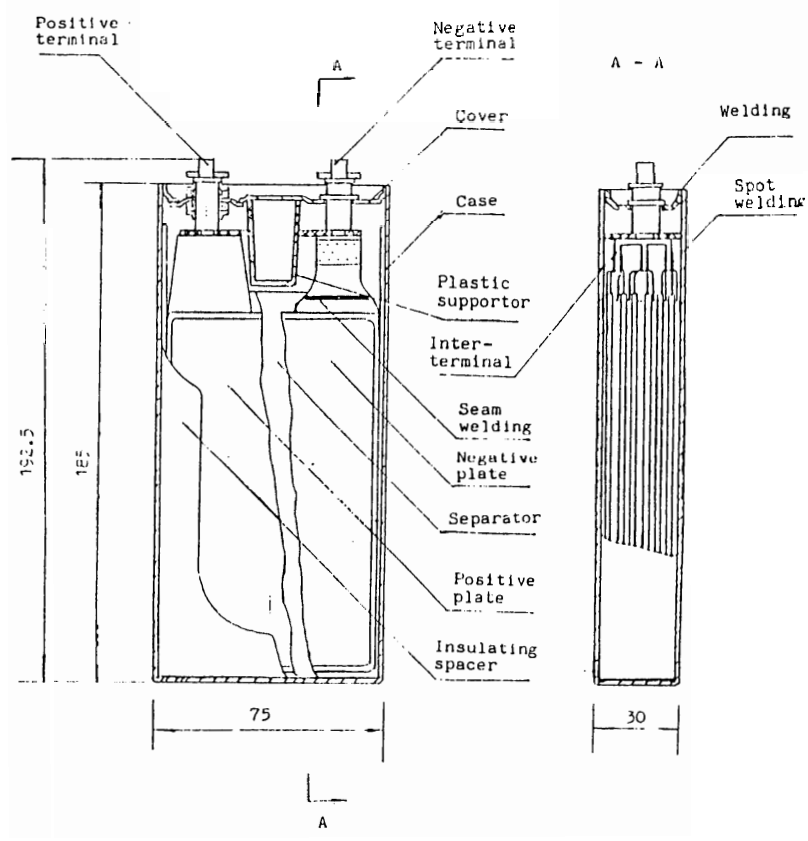

Fig. 9. Configuration of the Cell

DESIGN PARAMETERS The following thermal restriction are imposed to the battery:

a) operation temperature: -5 to $15 \mathrm{C}$.;

b) maximum temperature difference between cells

: $2 \mathrm{C}$;

c) maximum temperature difference between two points of the cell: $2 \mathrm{C}$.

The maximum and minimum average thermal dissipation during one orbit are $1.53 \mathrm{~W}$ and 0.55 W, respectively.

MODELIZATION HYPOTHESIS The following hypothesis was used in the thermal modelization of the bathery:

a) there is no radiation heat transfer through the battery surfaces, that is, the MLI is a perfect insulator;

b) the temperature of the panel, around the radiator, is not time dependent (boundary condition);

c) albedo and Earth radiation incident on the radiator are neglected.

THERMAL PROPERTIES OF MATERIALS The thermal properties adopted in the modelization are shown in the Table 4. The values are taken from the literature (1)(2)(3)(4)(5).

MODELIZATION OF THE CELL The cell was divided in two parts: one at botton side , comprising the region where the electrodes are placed; and the other at up side, comprising the region where the terminals and collectors are placed.

For each part, the effective conductivity 
and capacity are calculated. The Table 5 summarizes the results.

Table 4. Thermal properties of materials

\begin{tabular}{|c|c|c|c|}
\hline material & $\begin{array}{c}\text { conductiv } \\
W /(n * C)\end{array}$ & $\left|\begin{array}{l}\text { capacity } \\
\mathrm{J} /(\mathrm{Kg} \star \mathrm{C})\end{array}\right|$ & $\begin{array}{c}\text { density } \\
\mathrm{Kg} / \mathrm{m} 3\end{array}$ \\
\hline $\begin{array}{l}\text { stalnless steel } \\
\text { KoH } \\
\text { nylon } \\
\text { nickel } \\
\text { cadmitum } \\
\text { aluminium } \\
\text { kapton } \\
\text { silicone rubber } \\
\text { mylar } \\
\text { neg plate } 80 \% \mathrm{Ni} 20 \% \mathrm{KOH} \\
\text { pos plate } 80 \% \mathrm{Cd} 20 \% \mathrm{KOH} \\
\text { separator } 80 \% \text { nylon } 80 \% \mathrm{KOH} \\
\text { honeycomb panel }\end{array}$ & $\begin{array}{c}25.9 \\
0.30 \\
0.25 \\
58.6 \\
92.9 \\
189.0 \\
0.16 \\
0.39 \\
0.21 \\
46.9 \\
74.1 \\
0.291 \\
k_{x} 7.26 \\
k_{y} 5.51 \\
k_{z} 1.71\end{array}$ & $\begin{array}{r}502 \\
3432 \\
1674 \\
502 \\
230 \\
921 \\
1092 \\
1320 \\
1320\end{array}$ & $\begin{array}{ll}8.03 & 10^{3} \\
1.29 & 10^{3} \\
1.14 & 10^{3} \\
8.90 & 10^{3} \\
8.64 & 10^{3} \\
2.77 & 10^{3} \\
1.42 & 10^{3} \\
1.6 & 10^{3} \\
1.39 & 10^{3}\end{array}$ \\
\hline
\end{tabular}

Table 5. Effective condutivity and capacity of the cell

\begin{tabular}{|c|c|c|c|c|}
\hline property & $\underset{k_{x}}{\text { conduc }}$ & $\begin{array}{l}\text { vity } \\
\mathrm{k}_{\mathrm{y}}\end{array}$ & $\left.\right|^{W /(m * C)} k_{z}$ & $\begin{array}{l}\text { capacity } \\
\mathrm{J} /\left(\mathrm{m}^{3} * \mathrm{C}\right)\end{array}$ \\
\hline $\begin{array}{l}\text { botton } \\
\text { up }\end{array}$ & $\begin{array}{l}1.72 \\
0.80\end{array}$ & $\begin{array}{l}12.7 \\
1.71\end{array}$ & $\begin{array}{l}25.4 \\
2.61\end{array}$ & $\begin{array}{ll}2.69 & 10^{6} \\
0.48 & 10^{6}\end{array}$ \\
\hline
\end{tabular}

CALCULATION OF BATTERY TEMPERATURE TO calculate the battery temperature level and verify the temperature gradient between cells, a mathematical model is established (Complete Mode1).

The domain of the complete model comprises the radiator and the battery. The nodal breakdown is shown in the Figure 10. The mode1 is composed by 317 nodes, including 13 boundary nodes (one node representing the space and three nodes representing each side around the radiator).

The temperature of the pane1 around the radiator (used as boundary condition) was calculated during the battery compartment thermal analysis, and it is shown in the Figure 11 .

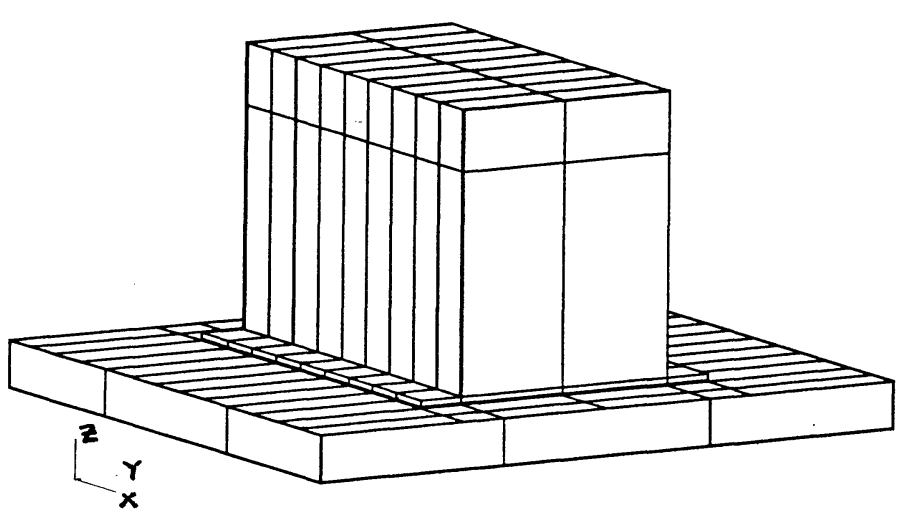

Fig. 10. Complete mode1 noda1 breakdown.

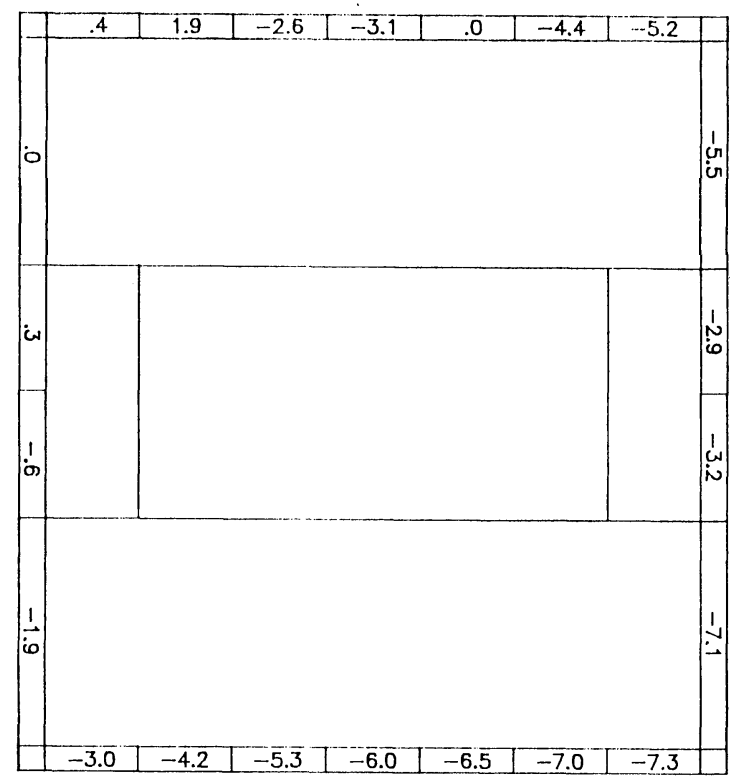

t. - - $x$

Fig. 11. Panel temperatures at boundary of radiator.

A contact conductance of $680 \mathrm{~W} /\left(\mathrm{m}^{2} * \mathrm{C}\right)$ (interface between Kapton and Aluminium) is considered in all interfaces between cells and intercalary plates, cells and base plates, cells and front and back plates. The effective conductivities of the plates (in transversal direction) are calculated.

The thermal contact resistance at the interface between silicone rubber and base plate 
or mounting panel is neglected.

There is no thermal conductance between two adjacent cells in y direction because there is no contact pressure in this direction.

The steady state condition is simulated, using maximum average internal dissipation ( 1.53 $W$ per cel1). The temperature is presented in the Figures 12 and 13 .

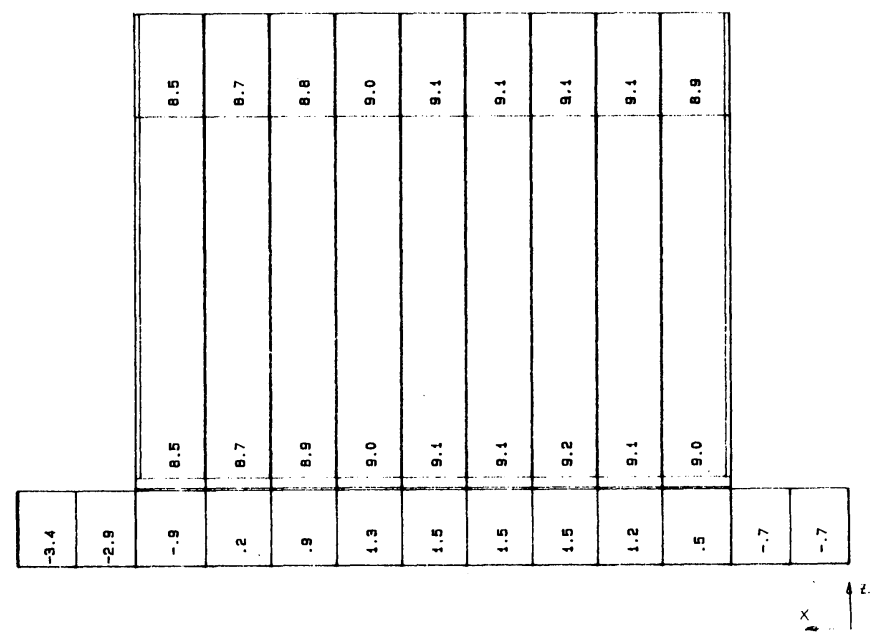

Fig. 12. Temperatures of the cells and the panel (plane $\mathrm{xz}$ )

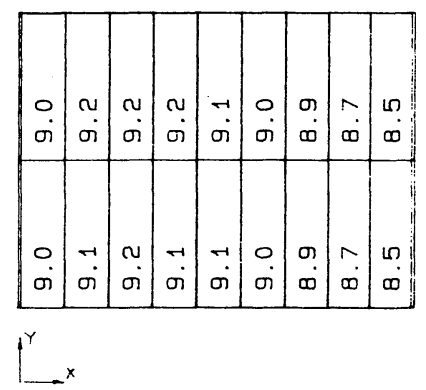

Fig. 13. Temperature of the cells (plane $x y$ )

The non symmetry of the cells temperatures related to the axis $x$ and $y$ is due to the non symmetry of boundary temperatures shown in the Figure 11. The difference of temperature between the first and nineth cells (Figure 12) is the contribution of non symmetry of boundary temperatures in the battery internal gradient, that is $0.5 \mathrm{C}$.

The gradient of battery temperature at $y$ direction is negligible.

The large gradient of temperature between base plate and panel is due to the low conductivity of the panel in $z$ direction, mainly. This gradient can be decreased using larger base plate.

CALCULATION OF THE CELL TEMPERATURE TO determine the temperature gradient in the cell, a second mathematical model is established (detailed model).

The detailed model comprises just a quarter of the domain of complete mode1, and presents a finer discretization. Each cell is divided in 5 nodes along the $z$ direction. The nodal breakdown is shown in the Figure 14. The model is composed by 114 nodes.

In this model the temperature of boundary of radiator is considered symmetrical in relation of axis $x$ and $y$. The used values are the mean of the temperatures shown in the Figure 11. For the side parallel to the $x$ axis, the imposed temperature is $-3.75 \mathrm{C}$ and to the $\mathrm{y}$ axis is $-2.65 \mathrm{C}$.

All surfaces in $x+$ and $y+$ direction are considered adiabatic.

A contact conductance of $680 \mathrm{~W} /\left(\mathrm{m}^{2 *} \mathrm{C}\right)$ is considered in all interfaces between cells and intercalary plates, cells and base plate, cel1 and front and back plates.

The thermal contact resistance at the interface between silicone rubber and base plate or panel is neglected.

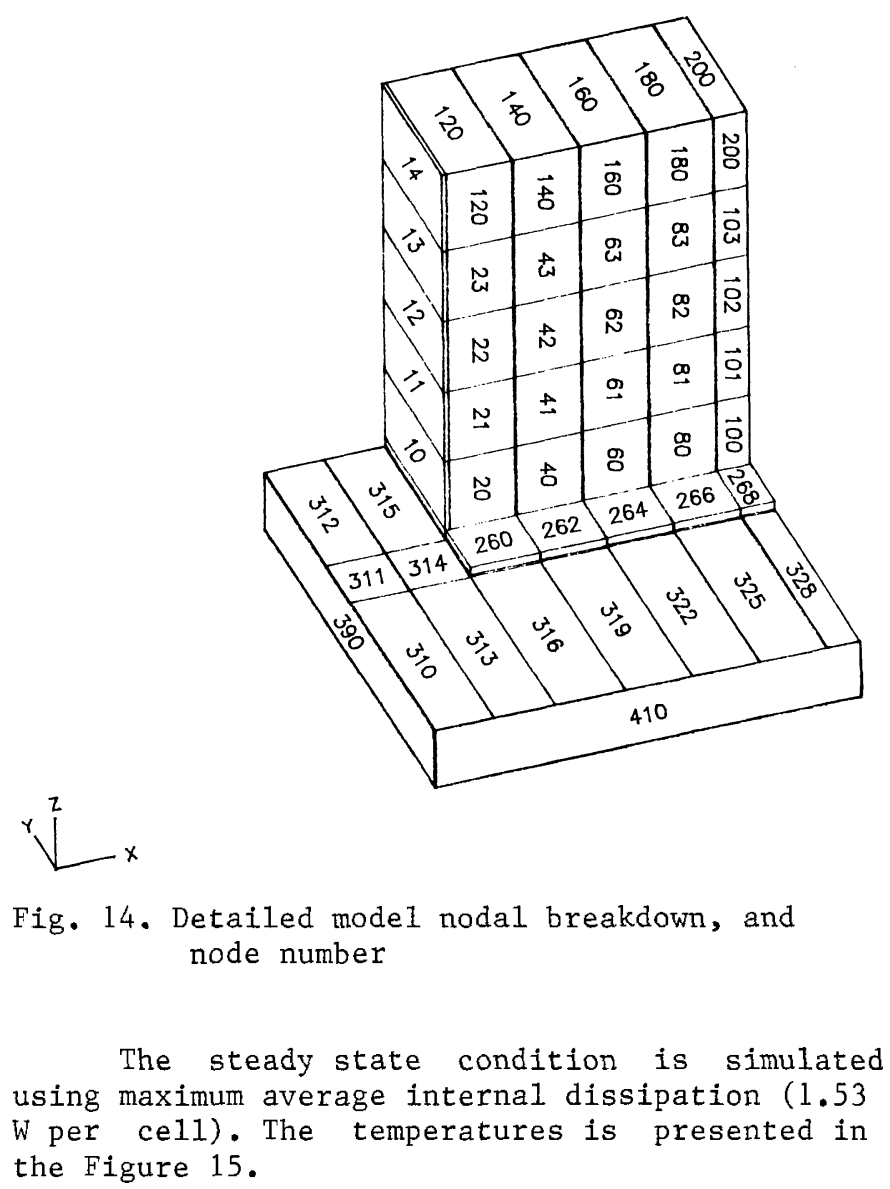




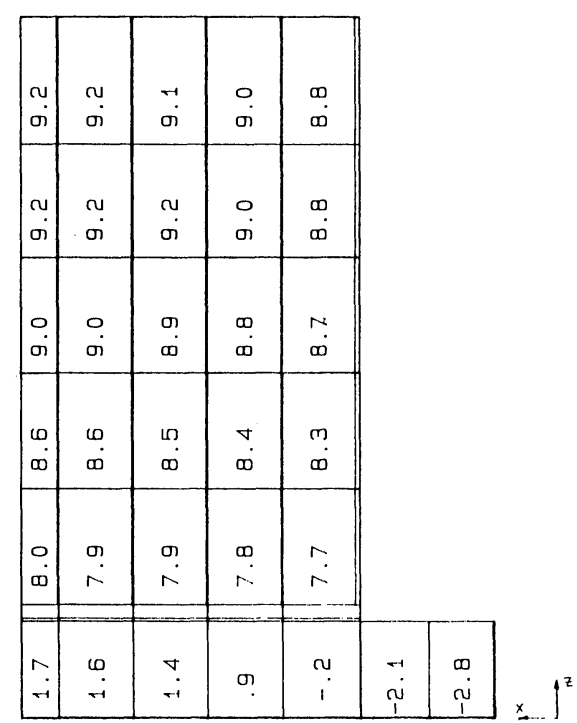

Fig. 15. Temperatures of the cells and the pane1 ( $\mathrm{plane} \mathrm{xz}$ )

The maximum difference of temperature between two points of the same cell is $1.3 \mathrm{C}$, that is below the specified limit of $2 \mathrm{C}$ (Figure 15).

Considering two points of different cells, the maximum difference of temperature is $1.5 \mathrm{C}$ (Figure 15). If the influence of non symmetry of radiator boundary temperature $(0.5 \mathrm{C}$ in the Figure 12) is considered, the maximum difference of temperatures in the battery can reach $2.0 \mathrm{C}$. This value is the specified limit.

\section{CONCLUSIONS AND COMMENTS}

1. The global thermal design conception of the satellite satisfies comfortably the temperature specifications. In this phase, the large margin, between predicted and allowed temperature, is desired considering the uncertanties of modelling and indefinitions of some input parameters.

2. The satellite thermal design and the matematical modelling will be checked by a thermal balance test on the thermal model. The test will be accomplish at the CAST laboratory using IR simulation.

3. Concerning to the battery compartment thernal analysis, the necessary heating power is very high due to a large difference of battery heat dissipation between the BOL and EOL, and the narrow range of the temperature specification.
4. The radiator area and heating power can be recalculated in a later phase of project when the battery compartment temperature, used as boundary condition, will be well known and its range of temperature can become narrower.

5. In the battery compartment analysis several other simulations were done in order to know the battery thermal behaviour, as sensitivity analysis related to heat dissipations and compartment temperature.

6 . The battery package design satisfy tightly the specified limit of internal temperature gradient (maximum of $2 \mathrm{C}$ ). Any increasing of internal heat dissipation causes the internal gradient exceeding the limit.

7. In the battery analysis several others analysis were done as sensitvity analysis related some unreliable parameters, and simulation of cold case with heater dissipation. 8. All the mathematical models used in the battery and its compartment analysis will be adjusted with experimental results from the battery compartment thermal test. This test will be accomplish at the INPE 1aboratory.

\section{REFERENCES}

1. D. P. Jennings. 1988. Thermal Analysis for SAR 8108 Battery. Joplin, MO, Eagle Picher, Electronic Division.

2.W. R. Scott and D. W. Rusta. 1979. Sealed Cel1 Nickel-Cadmium Battery Applications Manual. NASA RP 1052.

3. General Electric Company, Corporate Research and Development. 1979. Heat Transfer and Fluid Flow Data Book. Shenectady, NY

4. L. S. Fletcher, M. R. Cerza and R. L. Boysen. Thermal Conductance and Thermal Conductivity of Selected Polyethylene Materials in: AIAA 13th Aerospace Sciences Meeting, Calif., Jan. 20-22, 1975, AIAA paper 75-187.

5. Dupont Mylar Polyester Film. Technical Report. August, 1956. 